\title{
Sosiaali- ja terveyspalveluiden käyttö erityisperheiden arjessa - toiminnan ja ajankäytön näkökulma
}

Aluksi kaksi esimerkkiä viime vuosina julkaistuista erityislasten perheiden kokemuksista:

"On ikävää, kun joutuu koko ajan olemaan monelle kivenä kengässä. Herättelemään siihen, että lakia ei noudeta.” Näin sanoo ilomantsilainen äiti, joka perheineen on voittanut hallinto-oikeudessa jo kaksi oikeusjuttua Siun sotea vastaan. Niiden lisäksi yksi tapaus on parhaillaan hallinto-oikeuden käsittelyssä ja toinen poliisin esitutkinnassa. Kaikki ne liittyvät perheen erityislasten palvelujen myöntämättä jättämiseen.” Tämä oli poiminta sanomalehti Karjalaisesta 3. joulukuuta 2019. (1.)

"Mikset vaan antanut lastasi johonkin pois?" Näin otsikoi puolestaan Helsingin Sanomat 9. lokakuuta 2017. Uutisessa kerrotaan Kasper-pojan äidin arjen kokemuksesta. "Kasper saapui keskosena maailmaan. Hänellä on erilaisia diagnooseja yli kaksikymmentä. Kasper saa siis monenlaista tukea, nyt syksyllä myös hoitajan kotiinsa, koska äiti on alkanut opiskella. Ongelma on, että koska Kasperin sairauksia on niin monta, palvelujärjestelmä hänen ympärillään on sekava viidakko. Koska äiti ainoana tietää pojan tilanteen kokonaan, hänen ajastaan iso osa palaa byrokratiaan. 30 asiointipuhelua viikossa on ihan tavanomainen määrä.” (2.)

Nämä esimerkkitapaukset luovat kuvaa erityisperheiden kokemuksista heille kohdistettujen sosiaali- ja terveyspalveluiden hakemisesta ja käyttämisestä osana arjen toimintaa. Palveluiden, joiden tavoitteena on perheiden arjen toiminnan ja hyvinvoinnin tukeminen tai sen parantaminen.

Arjen hallinta -käsitettä tutkineen Liisa Haverisen mukaan perheenjäsenet pyrkivät sopeuttamaan toimintaansa eri jäsenten tarpeiden ja tilanteiden mukaan tavoitellessaan kotitalouden yh- teistä hyvinvointia (3). Perheissä, joissa on vähintään yksi erityistä tukea, hoitoa tai hoivaa tarvitseva lapsi, perheenjäsenet joutuvat sopeuttamaan arjen toimintansa tämän erityislapsen - tai lasten - tarvitseman ylimääräisen tuen ja hoidon mukaisesti. Tämän lisäksi nämä erityisperheet tarvitsevat arjen toiminnan ja hallinnan tueksi pitkäkestoisesti ja runsaasti erilaisia sosiaali- ja terveyspalveluita. Jotta elämä rullaisi. Ja että perheen arki olisi lähempänä niin kutsutun normiperheen arkea. Sillä ilman palveluita "elämä olisi katastrofaalista" kuten yksi väitöstutkimukseni haastateltavista toteaa.

Arkielämä ilman palveluita olisi kaaosta. Mutta millaista se on erilaisten palveluiden kanssa? Olen väitöskirjassani tutkinut sosiaali- ja terveyspalveluiden käyttöä erityisperheiden arjessa. Tutkimus tuottaa uutta ymmärrystä ja tietoa erityisperheiden arjen toiminnasta sekä siihen läheisesti kytkeytyvästä ajankäytön kokemuksesta. Tutkimus asemoituu palvelututkimuksen sekä kulutus- ja kotitaloustutkimuksen risteykseen, jossa yhdistävänä käsitteenä toimii arjen toiminta. Se toiminta, joka on löydettävissä meidän kaikkien arkielämästä kuten syöminen, lasten hoito, nukkuminen, työssäkäynti tai kodin ulkopuolisten instituutioiden kuten koulun ja päiväkodin kanssa toimiminen. Me jokainen voimme itseksemme pohtia, mitä teemme jokapäiväisessä elämässämme. Osan asioista teemme lähes tiedostamatta, kuten ehkä aamulla kahvin keittämisen ja sängyn petaamisen, sillä niistä on tullut meille rutiineja ja tuttuja käytäntöjä. Rutinoitumisen ansiosta meidän ei tarvitse juurikaan suunnitella tekemistä ja elämä tuntuu mukavalta ja sujuvalta. Ja kun tietyt toimet suoritetaan toistuvasti samaan aikaan päivästä, niiden jaksottuminen muodostaa meille tuttuja rytmejä, kuten vuorokausi- ja viikkorytmit.

Mutta elämään kuuluu myös arjen toimintojen konfliktit ja niiden aiheuttamat ajankäytön 
riitasoinnut. Elämä on harvoin muuttumattomassa "status quo" tasapainossa, sillä arjessamme tapahtuu jatkuvia keskeytyksiä, väliintuloja tai pysyviä muutoksia. Vanhemmiksi tulleet tietävät, miltä tuntuu, kun vauvan yöllinen itku herättää ja katkaisee unirytmin. Näitä rytmeissä tapahtuvia riitasointuja ranskalainen sosiologi Henri Lefebvre kuvaa englanninkielisellä sanalla "arrhytmia" eli rytmihäiriö (4). Kun arjen toimintaan ja ajankäyttöön kohdistuu ristiriitoja ja häiriöitä, perheet pyrkivät löytämään erilaisia keinoja ja toimenpiteitä palauttaakseen heille tutun arjen toiminnan melodian.

Erityislapsia ja -perheitä on aiemmin tutkittu etenkin sosiaali- ja terveystieteiden sekä kasvatus- ja yhteiskuntatieteiden näkökulmista. Niissä on keskitytty esimerkiksi autististen lasten tarvitseman hoidon ja tuen tarkasteluun (5), äitien kokemuksiin erityislasten hoidosta (6) tai perheiden selviytymisen ja sen tukemisen tarkasteluun (7). Tietoisuus erityislasten perheiden arjen haasteista on siis ollut olemassa jo pidemmän aikaa.

Tarkastelemalla väitöstutkimuksessani perheiden arjen toimintaa sekä palvelututkimuksen että kulutus- ja kotitaloustutkimuksen perinteistä käsin, luon uutta tietoa ja ymmärrystä siitä, mitä perheiden hyvinvoinnin parantamiseen tähtäävien palveluiden runsas ja pitkäkestoinen käyttö tuo tullessaan.

Tutkimuksen empiirisenä kohteena ovat perheet, joilla on ollut vuosien aikana käytössään jopa kymmeniä erityislapseen liittyviä palveluita käytössään. Väitän, että runsaasti ja pitkäkestoisesti palveluita tarvitsevien perheiden arkeen muodostuu uutta toimintaa, joka kytkeytyy palveluiden käyttöön ja jota nykyinen palvelujärjestelmä ei kykene tunnistamaan tai on kenties haluton tukemaan osana palveluntuotantoaan. Kyse on työlääksi käyvästä toiminnasta, jota ilman palveluiden käyttö on hankalaa tai se ei onnistu, ja joka syö perheen kokonaishyvinvoinnin kannalta arvokasta ja rajallista aikaa. Lisäksi palveluiden käyttö sekä erityislapsen hoito ja hoiva voivat aiheuttaa perheiden arkeen toiminnan ja ajankäytön rytmihäiriöitä, jotka vaikeuttavat arjen sujuvuuden kokemusta.

Perheen toiminnan tarkastelua motivoi yleinen pyrkimys saada sosiaali-ja terveyspalveluiden asiakkaat aktiivisemmiksi toimijoiksi suhteessa palveluiden käyttöön. Aktiivisuus voi näyttäytyä esimerkiksi osallistumisena palveluiden suunnit- teluun tai valintojen tekemiseen. Myönteistä ilmiössä on se, että monet asiakkaat aidosti haluavat ja kykenevät toimimaan itsenäisesti. He pystyvät hoitamaan monia tehtäviä, jotka ovat aiemmin olleet palveluntuottajien vastuulla. Terveysongelmiin liittyvän tiedon etsintä tai kotona tapahtuva omahoito ovat tästä hyviä esimerkkejä. Mutta on myös asiakasryhmiä, joiden kyvyt tai elämäntilanne eivät mahdollista heille siirtyvien tehtävien suorittamista. Nämä ovat usein niitä asiakkaita, jotka tarvitsevat monia palveluita omasta arjesta suoriutuakseen. Ja jos jokainen palvelu edellyttää ylimääräistä työtä, jokainen niistä myös syö asiakkaan jo lähtökohtaisesti rajallisia resursseja, kuten aikaa.

Niinpä palvelututkimuksen näkökulmasta asiakkaan toiminta ja käytännöt ovat erityisen merkittäviä tutkimuskohteita. Suosittuja tutkimusnäkökulmia ovat olleet esimerkiksi osallistuminen, sitoutuminen ja palvelun arvon yhteisluominen. Omassa tutkimuksessa keskityin tarkastelemaan asiakkaan tekemää toimintaa systemaattisesti ja yksityiskohtaisesti, mikä auttoi ymmärtämään erityisperheiden toiminnan määrää ja luonnetta sekä toiminnan ajankäytöllisiä paineita ja ristiriitoja. Väitöskirjani tuottaa uutta tietoa etenkin tilanteista, joissa palveluilla voidaan katsoa olevan pysyväluonteinen rooli ja merkitys osana arkielämää.

Esitän, että monien palveluiden vuosia kestävästä käytöstä voi aiheutua mittava määrä toimintaa, joka piiloutuu hajanaisesti ja eri tavoin toimivien palveluntuottajien näkökentän ulkopuolelle. Jokainen palvelu on luotu noudattamaan omaa toimintamalliaan ja aikarakennettaan. Asiakkaan suuntaan näyttäytyvästä palvelukokonaisuudesta puuttuu keskitetty taho tai toimija, joka varmistaisi monen palvelun helpon ja nopean käyttöönoton sekä niiden tavoitteen toteutumisen eli perheiden arjen toiminnan ja hyvinvoinnin tukemisen. Siksi erillisten palveluiden hakuprosessien ja käytön myötä perheiden arkeen syntyykin työläitä, hajanaisia ja aikaa vieviä toimintoja. Näitä ovat esimerkiksi vaikeaksi koettu tiedon etsintä, palveluita ja perheitä koskevan tiedon arkistointi ja jakaminen eli eräänlainen säilytys- ja postikonttorin rooli sekä monimuotoinen aikataulujen hallinta. Näistä kuormittavista toiminnoista syntyviä ongelmia tai epäkohtia nostinkin jo esiin puheeni alussa esimerkkitapausten kautta. 
Vanhemmat itse kuvailevat rooliaan projektijohtajan, välikäden ja viestinviejän metaforien kautta. Työhön ja työntekijän rooliin viittaavien kirjavien kuvauksien myötä nousee esiin tutkimuksen kenties yllättävin tulos. Vanhemmat ottavat tai joutuvat ottamaan jopa sote-alan ammattilaisia ohjaavan ja toimintaa kehittävän henkilön tehtäviä itselleen. Tällöin on mahdollista puhua esimiestason tehtävien valumisesta asiakkaalle. Päättäjien pohdittavaksi voidaankin esittää kysymys: muuttuvatko erityisperheet palveluiden asiakkaista palvelujärjestelmän työntekijöiksi tai palvelijoiksi?

Palveluiden käyttöön liittyvää toimintaa on tutkittu melko vähäisesti ajankäytön ja arjen sujuvuuden näkökulmasta. Oman kiinnostukseni aiheeseen herättivät erityisperheisiin kohdistuneet aiemmat tutkimukset, joissa lapsen tarvitsema tuki ja hoiva tunnistettiin vaikeasti ennakoitavaksi ja arjen rutiinien muodostusta hankaloittavaksi asiaksi. Tutkimukseeni osallistuneiden perheiden arki näyttäytyikin rikkonaiselta. Kun perheiden arkeen tulee erityislapsen hoivan lisäksi eri tavoin ja omilla aikarakenteillaan toimivat lukuisat palvelut, arkeen ilmaantuu samanaikaisesti kaksi, rytmillisiä hankauksia eli rytmihäiriöitä aiheuttavaa tekijää. Tällöin arjen ennakoiminen vaikeutuu ja tuttujen toimintojen toistuvuus vähenee, mikä koetaan arjen kaaostumisena. Perheen toiminta sirpaloituu ja päällekkäistyy. Päivät täyttyvät arjen rytmiä rikkovalla liikkumisella eri palveluntuottajien välillä. Kaikki nämä ilmiöt, yhdessä tai erikseen heikentävät perheiden kokemusta arjen hallinnasta. Pahimmillaan rytmihäiriöt koetaan jopa väkivaltaisina niiden kohdistuessa esimerkiksi perheenjäsenen biologiseen rytmiin vanhemman unensaannin häiriintyessä pitkäaikaisesti. Kuten tutkimuskin osoittaa, niin vanhemmat saattavat itse joutua sairaalahoitoon rytmittömän arjen aiheuttaman uupumuksen vuoksi.

Väitöskirjani päätyy tulkintaan siitä, että erityisperheiden ja palveluntuottajien yhteisen rytmin muodostumisessa painottuu tällä hetkellä palveluntuottajien määräämä toiminta, jossa ei oteta riittävästi huomioon erityisperheiden jo lähtökohtaisesti monimuotoista arjen toimintaa. Lisäksi palveluntuottajien omista aikarakenteista johdetut palveluajat ja -paikat aiheuttavat perheille monimuotoisia ajankäytön muutoksia ja paineita luoden riitasointuja arjen rytmeihin. Tul- kinnan myötä tutkimukseni herättää kysymyksen, että voisiko arkielämään sopivat, perheiden työmäärää ja ajankäyttöä helpottavat palvelut parantaa yhtäaikaisesti sekä palveluiden vaikutusta hyvinvoinnin kokemukseen että palveluiden tuotannon kokonaistehokkuutta?

Tutkimukseni yksi alkuperäinen kiinnostuksen kohde oli digitaalisten palveluiden käyttö. Koska haastateltavilla henkilöillä oli yllättävänkin vähän digitaalisia palveluita käytössään, päädyin tulkitsemaan digitaalisuuteen liittyviä kokemuksia osana muuta toimintaa. Keskeiseksi tulokseksi voi esittää sen, että perheet ovat huomattavasti valmiimpia käyttämään digitaalisia palveluita kuin mitä heille on tarjolla. Haastateltavilta tulikin monia konkreettisia ideoita palveluiden digitalisointiin liittyen, joiden toivon herättävän mielenkiintoa palveluntuottajien keskuudessa.

Tutkimus tuottaa kontribuutiota eli tieteellistä arvoa lisäämällä ymmärrystä sosiaali- ja terveyspalveluiden käytöstä osana erityisperheiden arjen toimintaa ja ajankäytön kokemusta. Aiempi palvelututkimuksen näkökulmasta tehty tieteellinen tarkastelu on rajoittunut käsittelemään asiakkaan ja palveluntuottajan välistä vuorovaikutusta tai arvon yhteisluontiin liittyviä käytänteitä, jättäen vähemmälle huomiolle asiakkaan arjessa tapahtuvan ja pitkälti asiakkaan ohjaaman, mutta palveluntuottajan näkökulmasta vaikeasti tunnistettavan toiminnan. Toiminnan, joka kuormittaa arkea ja kuluttaa asiakkaan rajallista aikaa ja voimavaroja. Toiminnan, joka näyttää paikkaavan palvelujärjestelmän virheitä ja ongelmia, ammattilaisten välisen vuorovaikutuksen puutteita ja jopa ammattilaisten osaamattomuutta. Toimintaa, jota perhe ja vanhemmat tekevät palvelutilanteiden pakottamana ilman aiempaa tietoa ja kokemusta tai sopivia työkaluja tai digitaalisia ratkaisuja.

Systemaattisen asiakkaan toiminnan analyysin lisäksi toiminnan ajallisen järjestäytymisen tarkastelu syventää pitkäkestoisen palveluiden käytön tulkintaa arjen hallinnan näkökulmasta.

Tutkimuksen hyödyntämä monialainen näkökulma luo pohjaa myös uusille mahdollisuuksille tarkastella palveluiden vaikuttavuutta. Kenties tulevaisuudessa sosiaali- ja terveyspalveluiden vaikuttavuutta voidaan arvioida entistä enemmän mittareilla, jotka kertovat palveluiden myönteisistä tai kielteisistä vaikutuksista ihmisten arjen 
toimintaan ja hyvinvoinnin kokemukseen. Sen sijaan, että mittaaminen tai arviointi keskittyisivät palveluiden kustannus- tai hintaseurantaan. Ajatus haastaa palveluntuottajia pohtimaan, millä lailla palvelut tulisi jatkossa suunnitella ja toteuttaa niin, että ne auttaisivat perheitä oman arjen rytmin löytämisessä sekä parantaisivat arjen sujuvuuden kokemusta.

Suomeakin koettelevan koronapandemian vuoksi kotiin eristäytyneet alle 10-vuotiaiden niin sanottujen normaalilasten perheet ovat ehkä saaneet hetkellisen kokemuksen siitä, miltä tuntuu kun vanhempi joutuu jäämään palkattomalle vapaalle, hoitamaan lasta kotiin ja rajoittamaan liikkumista. Hallitus tunnisti hienosti tämän muutostilanteen ja myönsi perheille väliaikaisen taloudellisen epidemiatuen, arvoltaan noin 720 euroa kuukaudessa (8).

Erityislapsen vanhempi voi hakea Helsingissä 432 euron arvoista kuukausittaista omaishoidon tukea jatkuvaa valvontaa edellyttävän tai esimerkiksi itsetuhoisesti käyttäytyvän lapsen vuoksi. Nämä vanhemmat voivat joutua vähentämään työtekoa tai lopettamaan palkkatyön kokonaan aivan vastaavasti kuten epidemiatuen saavat vanhemmat. Saadakseen seuraavan hoitoluokan eli epidemiatukea vastaavan, yli 700 euron arvoisen omaishoidontuen, lapsen hoidon ja valvonnan on jo oltava luonteeltaan pääsääntöisesti ympärivuorokautista eli myös yöhoitoa vaativaa. Tukea saadakseen perheen on myös täytettävä tarkka pisteytyskriteeristö. (9.) Tutkimuksen osoittaman, perheille lankeavan työmäärän perusteella olisikin ehkä aika arvottaa erityisperheissä tehtävän työn arvo uudelleen.

Toivon, että tieteellisen tiedon lisäksi tutkimus tuottaa käytännön työhön tietoa, joka auttaa ammattilaisia tunnistamaan sekä erityisperheet palveluiden käyttäjinä että heidän jokapäiväiset haasteensa. Ehkä yksi tapa kehittää nykyisten sosiaali- ja terveyspalveluiden vaikuttavuutta voisikin olla läheisemmän tutkimusyhteistyön tekeminen esimerkiksi palvelututkimuksen kanssa. Lisäksi palveluiden järjestämistä ja tuotantoa kehittäessään palveluntuottajat voisivat hyödyntää nykyistä enemmän kulutustutkimuksen ja liiketaloustieteen koulutuksen saaneita henkilöitä. Uskon, että palveluiden järjestämiseen tarvittavan osaamisen monimuotoistaminen tarjoaisi erilaisia näkemyksiä sote-alalla tunnistettujen rakenteellisten haasteiden ratkomiseen.

\section{LÄHTEET:}

1. Karjalainen. "Taiskelkaa, jotta asiat muuttuvat", Hanna Hurskainen painottaa - Siun soten täytyy järjestää ilomantsilaiselle erityislapselle hänen tarvitsemansa palvelut, linjaa hallinto-oikeus. 3.12.2019. Luettu 19.10.2020. https:/www.karjalainen.fi/uutiset/uutis-alueet/ maakunta/item/236274? fbclid=IwAR0vnZdKz FhfJlShN-4IAAH0Y4nbkqjMONs_Mho57X3e9yt0xHbK7yZyI4

2. Helsingin Sanomat. "Mikset vaan antanut lastasi johonkin pois?” - Pian nelivuotiaan Kasper-pojan äiti Jenni Arteli ihmettelee, miksei omaishoitajia oikeasti arvosteta. 9.10.2017. Luettu 19.10.2020. https://www.hs.fi/kaupunki/art-2000005400605. html

3. Haverinen L. Arjen hallinta kotitalouden toiminnan tavoitteena. Kotitalouden toiminnan filosofista ja teoreettista tarkastelua. Tutkimuksia 164. Helsinki: Helsingin yliopisto: 1996.

4. Lefebvre H. Rhythmanalysis: Space, time and everyday life. Athlone, Contemporary European Thinkers. London: Continuum: 1992/2004.

5. Schaaf RC, Toth-Cohen S, Johnson SL, Outten G, Benevides TW. The everyday routines of families of children with autism. Examining the impact of sensory processing difficulties on the family. Autism: The International Journal of Research and Practice 2011;16(6): 373-389.

6. Kellegrew DH. Constructing daily routines: A qualitative examination of mothers with young children with disabilities. The American Journal of Occupational Therapy 2000; 54 (3): 252-259.

7. DeGrace BW. The Everyday Occupation of Families With Children With Autism. The American Journal of Occupational Therapy 2004; 58(5): 543-550.

8. Kansaneläkelaitos. Väliaikainen etuus koronaepidemian takia palkattomalla vapaalla oleville. 27.4.2020. Luettu 19.10.2020. https:// www.kela.fi/ajankohtaista-henkiloasiakkaat/-/ asset_publisher/kg5xtoqDw6Wf/content/ valiaikainen-etuus-koronaepidemian-takiapalkattomalla-vapaalla-oleville

9. Helsingin kaupunki. Omaishoidon tuet. 14.9.2020. Luettu 19.10.2020. https://www.hel.fi/seniorit/fi/ apua/omaishoito/omaishoidon-tuet/

\section{ULLA SÄRKIKANGAS \\ Filosofian tohtori \\ Helsingin yliopisto}

Kauppatieteiden maisteri Ulla Särkikankaan väitöskirja Sosiaali- ja terveyspalveluiden käyttö erityisperheiden arjessa - toiminnan ja ajankäytön näkökulma tarkastettiin Helsingin yliopiston Maatalous-metsätieteellisessä tiedekunnassa 10.6.2020. Vastaväittäjänä toimi professori Outi Uusitalo Jyväskylän yliopistosta ja kustoksena professori Anne Toppinen Helsingin yliopistosta. 